\title{
Student commitment to social responsibility: Systematic literature review, conceptual model, and instrument
}

\author{
Fabio Arroyave ${ }^{1,2}$ (ID), Angels Dasî ${ }^{3}$ (D), Ana Redondo ${ }^{3}$ (D) \\ ${ }^{1}$ IDINNOV research group, IDINNOV S.A.S., Medellin (Colombia) \\ ${ }^{2}$ Universitat de València, Valencia (Spain) \\ ${ }^{3}$ Department of Management 'Juan JoséC Renau Piqueras', Universitat de València, Valencia (Spain) \\ farroyave@idinnov.com,Angels.Dasi@uv.es,ana.redondo@uv.es
}

Received August, 2020

Accepted June, 2021

\section{Abstract}

Purpose: This study aims to carry out a systematic literature review on empirical manifestations of the student commitment to social responsibility in order to propose a conceptual model that systematizes the underlying patterns in these manifestations and an instrument that makes it measurable.

Design/methodology: Four macro-processes were deployed: identify (locate the relevant literary space; the initial sample comprised 52 studies which later resulted in a sample of 24 studies), describe (narrative synthesis of the studies), deepen (grouping patterns, validation, and characterization of the relevant literary space), and disseminate (preparation/refinement of the report).

Findings: This work provides a conceptual model comprising six dimensions about student commitment to social responsibility as well as a validated instrument at the content level that makes these dimensions empirically observable/measurable.

Practical implications: Insights are provided to focus efforts and organizational resources to develop the commitment addressed.

Originality/value: The proposed model and instrument provide greater clarity and homologation on the conception, composition, and empirical manifestations of the student commitment to social responsibility and its future measurement.

Keywords: Social responsibility, Commitment to social responsibility, Systematic review, Student

Jel Codes: M14

\section{To cite this article:}

Arroyave, F., Dasí, A., Redondo, A. (2021). Student commitment to social responsibility: Systematic literature review, conceptual model, and instrument. Intangible Capital, 17(1), 52-72. https://doi.org/10.3926/ic.1685

\section{Introduction}

Universities are benchmarks in society and are also educators of young students who will be tomorrow's future professionals. The current environment is full of social, environmental, and economic problems that have increased catastrophically due to COVID-19 (ECLAC, 2020). This further compromises universities in their role as promoters of social welfare. 
This role demands that universities manage their teaching, research, and extension dimensions to training professionals with ethical values and sensitivity towards current problems so that they can contribute to the benefit of society (Bhattacharyya \& Rahman, 2020; Claver-Cortés et al., 2020; Garde Sánchez, Rodríguez Bolívar \& López-Hernández 2013; Ralph \& Stubbs, 2014).

From a general perspective, this contribution can be assumed to be a reasonable expression of students' commitment to social responsibility (SR), in whose development universities play a leading role. According to Galvão, Mendes, Marques and Mascarenhas (2019), the socially responsible act of organizations will depend, to a large extent, on aspects such as the attitudes, beliefs, and values of future professionals. In addition, Galvão et al. (2019) point out that these aspects can be nurtured or drained in terms of socially responsible criteria throughout the students' academic life.

Therefore, it is essential that universities develop student commitment to SR throughout the curriculum. These efforts merit the incorporation of ethical, social, and environmental aspects in the study plans to promote students' sensitivity, reflections, conceptualizations, and behaviors that satisfy organizations and their stakeholders (Holland, 2004; Rodríguez-Gómez, Garde-Sánchez, Arco-Castro \& López-Pérez, 2020). This mission becomes even more relevant when considering that university students' attitudes represent a reasonable indicator of their academic and professional performance (Larrán, Andrades \& Herrera, 2018).

Research of student commitment to SR is a topic with increasing interest in the academic community. However, given the diversity of observation contexts and analysis perspectives, it is still complex and confusing to identify underlying patterns in SR aspects from the student perspective. So, there is an emerging need to deepen that "reconciliation between order and chaos", "function of the perceived world and attributes of the real world" (Lockhart-Nelson, 2017, p. 1), or the "common denominator between multiple instances of an entity" (Parasher, Sharma, Sharma \& Gupta, 2011, p. 371), in this case regarding the student commitment to SR.

Identifying such underlying patterns (e.g., models and taxonomies) is essential to consensus about what are the critical components of student commitment to SR. Enabling this consensus is necessary due to a high diversity of empirical manifestations of this commitment, including showing concern for sustainability (Berény \& Deutsch, 2017; Larrán et al., 2018), generating discussion on SR issues (Reis, von Schwedler \& Gomes, 2015), recognizing SR as a factor of business success (Alonso-Almeida, Fernández de Navarrete \& Rodriguez-Pomeda, 2015), and being aware of the damages that destructive behaviors in students/practitioners can generate insociety (Lin \& Loui, 2017).

In other words, despite the valuable contributions of previous work, there are still no agreed positions on what defines and composes student commitment to SR. The empirical manifestations of this commitment have not been consolidated, homologated, synthesized, and systematized, considering the available evidence, so that these can be accessible to researchers and professionals interested in the topic.

A study that addresses such a knowledge gap would make it possible to favor two fronts of implications. The first is providing a framework (model and instrument) for carrying out subsequent work to measure this construct (student commitment to SR) and its relationship with other variables using structural approaches. The second is providing insights that would facilitate the leaders of educational institutions as follows: (a) recognize the fundamental components of students' commitment to SR; (b) focus efforts and resources for the development of this commitment; and (c) increase organizational maturity in terms of socially responsible aspects.

The present work aims to carry out a systematic literature review on the empirical manifestations of the student commitment to SR in order to propose a conceptual model that systematizes the underlying patterns in these manifestations and an instrument that makes it measurable.

To achieve this objective, we define three work fronts. The first comprises the location and characterization of relevant studies on the subject, using reproducible procedures open to scrutiny, under the systematic literature review approach. The second front encompasses the extraction, homogenization, grouping, and synthesis of evidence, using a pattern discovery procedure based on critical incidents and agreement between judges. This last front provides the conceptual model of interest, which gives efficient access to a synthesis of the analyzed 
evidence and stimulates strategic decision-making processes. The third aspect makes the conceptual model measurable by providing (a) concrete items that summarize the main empirical manifestations of the student commitment to SR and (b) content validation of these items through experts.

In general, defining and measuring SR and its facets (e.g., commitment to SR) continues to be a topic of growing interest, but it is unclear at a theoretical and methodological level (Blowfield \& Frynas, 2005; Ibe, Min, Ling, \& Yii, 2015; Jensen, 2016). Without a deep understanding of what such constructs represent and how they are manifest, their diagnosis, development strategies, and implied impacts (e.g., on individual and organizational performance) are questionable. This article contributes to a more comprehensive understanding of student commitment to SR at a conceptual and instrumental level. It is supported by collecting, synthesizing, and classifying findings from relevant empirical works on the subject. Thus, this paper stimulates future independent studies focused on discovering antecedents and consequences of the six proposed dimensions of the analyzed commitment. The provided model and instrument make it possible to find new explanations for the decisions and behaviors of graduates throughout their professional practice as employees or leaders of business organizations. For example, the proposed dimensions are helpful in nurturing existing structural models aimed at explaining dichotomies in the graduate/employee/leader, such as transparency/corruption (Peisakhin, 2012), control/empowerment (Lewis, Brown \& Sutton, 2019), transformational/transactional leadership (Bass, Avolio, Jung \& Berson, 2003), and individualism/collectivism (Kagitcibasi, 1997).

In the proposed model and instrument, organizational leaders can find a synthesis of the main facets representing the student commitment to SR. Also, this serves as a basis/guide for future identification, prioritization, and evaluation of organizational strategies around the topic.

This document consists of six sections. Section 1 provides the introduction. Section 2 explains the systematic review protocol. Section 3 describes the "Relevant Literary Space" (RLS, Pérez-Rave, 2012), which constitutes the finally selected sample. Next, that same section provides and discusses the characterization of the RLS using frequency tables and graphs. Then, the conceptual model of student commitment to SR is exposed and described. Subsequently, this model is made measurable through specific items, and evidence of its content validation is provided. Section 4 presents the general conclusions of the study. Section 5 presents the limitations, and Section 6 provides suggestions for future work.

\section{Methods}

The development of the study is supported by the general approach of a systematic review which, considering Torgerson (2003) and Denyer and Tranfield (2009), consists of planning the review, defining the review protocol, locating/selecting the studies, analyzing/synthesizing the evidence, and preparing the report. Regarding the detailed procedure, the methodological framework proposed by Pérez-Rave (2012; 2019) was used. This consists of four macro-processes: identify (the RLS), describe (narrative synthesis of the studies), deepen (characterization, identification of underlying patterns and validation), and disseminate (elaboration and refinement of the manuscript).

\subsection{Identify}

The inclusion/exclusion criteria of the studies under review are presented below:

1. Studies published by journals indexed in Scopus, which implies that they meet academic quality standards, employ peer review, are punctual in editing, and have a prestigious editorial team, among other aspects verified by a group of researchers and librarians associated with Scopus (DICE, 2010).

2. Studies published by journals in organization management (Engineering, Business, Decision Sciences, Social Sciences, Economics).

3. Studies published during 2015-2019 (last five years from the moment of the search).

4. Only primary studies (review articles, reflections, editorial notes, book chapters, etc. are excluded).

5. Studies evaluate at least one facet of the student commitment to SR.

Figure 1 shows the search algorithm used in Scopus to locate the initial sample of the documents of interest. 
TITLE (cSr OR "corporate social responsibility" OR "responsible entrepreneurship" OR "social responsibility" OR "social business responsibility") AND TITLE (student) AND (LIMIT-TO (DOCTYPE, "ar") OR LIMIT-TO (DOCTYPE, "cp") OR LIMIT-TO (DOCTYPE, “ip”)) AND (LIMIT-TO (SUBJAREA, “BUSI”) OR LIMIT-TO (SUBJAREA, "SOCI") OR LIMIT-TO (SUBJAREA, “ECON") OR LIMIT-TO (SUBJAREA, “ENGI”) OR LIMIT-TO (SUBJAREA, “DECI")) AND (LIMIT-TO (PUBYEAR, 2019) OR LIMIT-TO (PUBYEAR, 2018) OR LIMIT-TO (PUBYEAR, 2017) OR LIMIT-TO (PUBYEAR, 2016) OR LIMIT-TO (PUBYEAR, 2015))

Figure 1. Search algorithm deployed in Scopus on February 8, 2019

There is no consensus about the minimum number of articles necessary to carry out a systematic literature review (Albliwi, Antony \& Lim, 2015). However, it is required to report the number of documents recovered (initial sample) based on representative and reproducible search algorithms about the study topic. Also, it is necessary to inform the number of articles that passed the final filter based on the other precise and supported inclusion/exclusion criteria (Pérez-Rave, 2019; Torgerson, 2003). For example, Beyene, Sheridan and Aspden (2014) reported a final sample of 19 articles, Watkins and Xie (2004) 23 articles, and Kim and Xie (2015) 42 articles.

Under these considerations, following the search algorithm (see Figure 1), the initial sample was comprised of 52 articles. Note that the algorithm automatically filtered the areas of the journals (i.e., Busi: Business) and the period of interest (2015-2019). The types of documents allowed were articles (ar), conference papers (cp), and articles in the press (ip) which facilitate recovering documents consistent with the IMRyD structure (introduction, methods, results, and discussion). In addition, two groups of search terms were used. The first represents the concept of social responsibility, and the second represents the student context. The search algorithm also ensured that both groups of terms are in the title of the documents, which implies that these expressions are the main topics of the manuscripts. The algorithm also automatically allowed one to verify most of the inclusion/exclusion criteria previously exposed. However, this filter does not ensure that all criteria are met. Hence, a manual verification was carried out, which included revising the title and the abstract of each document. This second filter resulted in 24 documents that satisfy all of the inclusion/exclusion criteria, equivalent to $46 \%$ percent of the initial sample (52).

\subsection{Describe}

An article description format (Pérez-Rave, 2019) was used. This facilitated synthesizing the studies of interest considering general bibliometric aspects (journal, quartile, etc.) and answers to questions about the content of the article in terms of what was done? Why? How? What was found? What was concluded? What challenges are proposed? What limitations are there? This macro-process allows a reasonable understanding of each document separately, understanding its context, recognizing its lexical (words) and syntactic (phrases) conformation (relevant to the present study) as well as having theoretical-methodological bases to plan and proceed with the following macro-process (deepen).

\subsection{Deepen}

This macro-process comprises two stages. In the first stage, the RLS was characterized according to the characteristics of interest, addressing contextual and methodological aspects of the construct under study. Then, a matrix of categorical/binary variables was built, and later descriptive statistics were estimated (e.g., frequency analysis, using SPSS). In the second stage, following Pérez-Rave (2019), a procedure similar to the critical incident collection method (Hayes, 1995) was deployed, considering the documents included in the RLS. In this case, it means understanding critical incidents as concrete/specific empirical manifestations of the student commitment to SR (86 critical incidents were collected). Later, a procedure of pattern discovery was carried out using a method of agreement between judges (Hayes, 1995). Initially, two judges jointly formed homogeneous groups of critical incidents (previously documented on post-it notes), considering the semantic similarity between them, which resulted in "elements". Next, we repeated this activity between elements (groups of critical incidents), emerging a set of initial underlying dimensions of student commitment to SR. After that, labels were assigned to the dimensions, considering their meanings and based on the interpretivism and literature review. After that, a third judge executed the process in reverse: he assigned the elements to the proposed dimensions. 
At the final stage of the process, the agreement between the two rounds of judges was analyzed. The dimensions that achieved at least 70\% agreement were accepted, and the remaining discrepancies were resolved by finding a consensus among the judges. This activity generated the preliminary conceptual model (dimensions, meanings, interpretation) and instrument (measurement scale comprising empirical manifestations, in item format, which describe the elements that made up the dimensions).

After the above, the content validation of such dimensions was carried out (the degree to which each dimension measures the expected content area, Gay, 1980). For this purpose, a validation form was developed in a matrix format which included the formulated items (rows) and two variables (columns: clarity and relevance) rated at five points, with 1 being the worst rating and 5 the best. This form was administered to 10 experts in areas of organization management. After tabulating the data, descriptive statistics of the central tendency and variation were calculated. Then, we immediately accepted each item that (a) exceeded the average score of 4.0 in both variables (clarity and relevance) and, at the same time, (b) none of the ten evaluators assigned a rating of 1 or 2 to the item. When (a) or (b) were not satisfied, the item was reviewed to identify the reasons for its scores and to analyze the need and alternatives for refinement/exclusion/conservation of the item, considering the authors' viewpoint and suggestions (open question) from the experts.

\subsection{Disseminate}

This macro-process focused on documenting the study based on guidelines from scientific writing. Thus, it starts with an initial version, then comes its verification and refinement, both from the authors' perspective and from the peer review.

\section{Results and discussion}

\subsection{Relevant Literary Space identified}

Table 1 lists the 24 studies that make up the RLS under review.

\begin{tabular}{|c|c|c|c|c|c|c|}
\hline Id & Study & Journal & Country & SJR & H-index & Quartile \\
\hline 1 & Galvão et al., 2019 & Journal of Cleaner Production & Netherlands & $1.47(2017)$ & 132 & Q1 \\
\hline 2 & Da Silva Junior et al., 2019 & Journal of Cleaner Production & Netherlands & $1.47(2017)$ & 132 & Q1 \\
\hline 3 & Larrán et al., 2018 & Spanish Accounting Review & Spain & $0.345(2018)$ & ND & Q3 \\
\hline 4 & Smith et al., 2018 & $\begin{array}{l}\text { American Society for } \\
\text { Engineering Education }\end{array}$ & United States & ND & ND & ND \\
\hline 5 & Nittala et al., 2018 & $\begin{array}{l}\text { American Society for } \\
\text { Engineering Education }\end{array}$ & United States & ND & ND & ND \\
\hline 6 & Teixeira et al., 2018 & Public Nonprofit Mark & Germany & $0.19(2017)$ & 9 & Q3 \\
\hline 7 & Silva et al., 2018 & Social Responsibility Journal & United Kingdom & $0.43(2018)$ & 23 & Q2 \\
\hline 8 & $\begin{array}{l}\text { Fowler, Noronha, Rosendo, } \\
\text { Ribeiro \& Gonçalves, } 2018\end{array}$ & $\begin{array}{l}\text { International Symposium on } \\
\text { Project Approaches in } \\
\text { Engineering Education }\end{array}$ & Brazil & ND & ND & ND \\
\hline 9 & $\begin{array}{l}\text { Vallaeys \& Álvarez } \\
\text { Rodríguez, } 2018\end{array}$ & Education XXI & Spain & $0.61(2018)$ & 13 & Q2 \\
\hline 10 & $\begin{array}{l}\text { Belyaeva, Scagnelli, } \\
\text { Thomas \& Cisi, } 2018\end{array}$ & $\begin{array}{l}\text { World Review of } \\
\text { Entrepreneurship, Management } \\
\text { and S. Development }\end{array}$ & United Kingdom & $0.24(2018)$ & 13 & Q3 \\
\hline 11 & Shaidullina et al., 2018 & Espacios & Venezuela & $0.16(2018)$ & 12 & Q3 \\
\hline 12 & Lin \& Loui, 2017 & $\begin{array}{l}\text { IEEE Frontiers in Education } \\
\text { Conference }\end{array}$ & United States & $3.76(2018)$ & 326 & Q1 \\
\hline 13 & Pätäri et al., 2017 & Forest Policy and Economics & Finland & $1.33(2018)$ & 60 & Q1 \\
\hline 14 & Haski et al., 2017 & Journal of Business Ethics & Australia & $1.86(2018)$ & 147 & Q1 \\
\hline 15 & Zizka, 2017 & $\begin{array}{l}\text { Journal of Teaching in Travel \& } \\
\text { Tourism }\end{array}$ & Switzerland & $0.31(2018)$ & 19 & Q3 \\
\hline
\end{tabular}




\begin{tabular}{|c|c|c|c|c|c|c|}
\hline Id & Study & Journal & Country & SJR & H-index & Quartile \\
\hline 16 & $\begin{array}{l}\text { Martínez Usarralde, Lloret- } \\
\text { Catalá \& Mas-Gil, } 2017\end{array}$ & $\begin{array}{l}\text { Education Policy Analysis } \\
\text { Archives }\end{array}$ & United States & $0.82(2018)$ & 40 & Q1 \\
\hline 17 & $\begin{array}{l}\text { Burga, Leblanc \& Rezania, } \\
2017\end{array}$ & $\begin{array}{l}\text { The International Journal of } \\
\text { Management Education }\end{array}$ & Canada & $0.57(2018)$ & 16 & Q2 \\
\hline 18 & Berényi \& Deutsch, 2017 & $\begin{array}{l}\text { Weas Transactions on Business } \\
\text { and Economic }\end{array}$ & Hungary & $0.14(2018)$ & 14 & Q4 \\
\hline 19 & Murphy et al., 2019 & Journal of Business Ethics & Saudi Arabia & $1.86(2018)$ & 147 & Q1 \\
\hline 20 & Sánchez \& Mainardes, 2016 & $\begin{array}{l}\text { International Review on Public } \\
\text { and Nonprofit Marketing }\end{array}$ & Brazil & $0.24(2018)$ & 11 & Q3 \\
\hline 21 & $\begin{array}{l}\text { Vázquez, Aza \& Lanero, } \\
2016\end{array}$ & $\begin{array}{l}\text { International Review on Public } \\
\text { and Nonprofit Marketing }\end{array}$ & Spain & $0.26(2018)$ & 11 & Q3 \\
\hline 22 & Da Silva et al., 2019 & London Business School Review & Spain & $1.72(2018)$ & 25 & Q1 \\
\hline 23 & Reis et al., 2015 & $\begin{array}{l}\text { Proceedings of the European } \\
\text { Conference on Knowledge } \\
\text { Management, ECKM }\end{array}$ & Portugal & ND & ND & ND \\
\hline 24 & Rulifson, 2015 & $\begin{array}{l}\text { American Society for } \\
\text { Engineering Education }\end{array}$ & United States & ND & 6 & ND \\
\hline
\end{tabular}

Table 1. Selected RLS

Table 1 shows that the SJR (Scimago Journal Rank) index ranges from 0.14 to 3.76 (ranking 2017 or 2018 ). The H-index varies between 6 and 326. Regarding the quartile of the journals, the majority (62\%) are classified in Q1 or Q3; the remaining percentage corresponds to Q2 (12.5\%) and finally Q4 (4.2\%), and the additional were derived from conferences $(21 \%)$. The geographical areas where the publications were made correspond to European countries(54\%), followed by theUnited States, Canada, Australia, Venezuela, and Brazil.

\subsection{Deepening the RLS}

This section provides methodological and content aspects of the construct of interest.

\subsubsection{Methodological aspects}

\section{- Type of study}

Table 2 describes the type of study used by the works that make up the RLS.

\begin{tabular}{|l|r|r|r|}
\hline \multicolumn{1}{|c|}{ Type of Study } & Frequency & Percentage & Accumulated percentage \\
\hline Quantitative & 14 & 58.33 & 58.33 \\
\hline Qualitative & 8 & 33.33 & 91.66 \\
\hline Mixed & 2 & 8.33 & 100.0 \\
\hline Total & $\mathbf{2 4}$ & $\mathbf{1 0 0}$ & $\mathbf{1 0 0}$ \\
\hline
\end{tabular}

Table 2. Type of Studies

Table 2 shows that 14 of the articles reviewed are quantitative and correspond to $58.33 \%$ of the sample; eight are qualitative (33.33\%), and two are mixed (8.3\%). Among the quantitative studies is Galvão et al. (2019), who propose a quantitative model derived from applying a questionnaire to a greater number of students. In addition to sociodemographic data, Galvão et al. (2019) asked students about personal values, covering a sample of 249 undergraduate students and 68 master's students. Galvão et al. (2019) performed several analyzes, including correlation analysis, t-tests, and analysis of variance (ANOVA), to understand what factors influence students' corporate social responsibility orientation. They used the IBM-SPSS Statistics version 21 software. Another quantitative study was done by Belyaeva et al. (2018) who applied an online survey to 426 (320 valid responses) undergraduate and graduate students enrolled in business programs at three universities in France, Italy, and Russia. They used stratified random sampling to obtain representative data covering a relatively uniform distribution of different population groups. The sample considered the country of study, gender, and the current higher education program in which the students were enrolled. Descriptive statistics and ANOVA were estimated. The authors used a variance-based structural equations approach under PLS-SEM. 
Shaidullina, Zakirova, Kashurnikov, Arestova, Shmidt and Kovaleva (2018) carried out another qualitative study. They analyzed social and pedagogical characteristics of a student preparation process in a university study center that trained for an innovative business field. Among other aspects, they considered social responsibility competencies. The results confirmed the theoretical and practical importance of including students' social responsibility activities in the educational process and their projection in the business environment.

\section{- Temporality}

Table 3 characterizes the RLS according to cross-sectional and longitudinal studies.

\begin{tabular}{|l|r|r|r|}
\hline \multicolumn{1}{|c|}{ Temporality } & Frequency & Percentage & Accumulated percentage \\
\hline Cross-sectional & 20 & 83.3 & 83.3 \\
\hline Longitudinal & 4 & 16.7 & 99.9 \\
\hline Total & $\mathbf{2 4}$ & $\mathbf{1 0 0}$ & $\mathbf{1 0 0}$ \\
\hline
\end{tabular}

Table 3. Temporality of Studies

Table 3 describes the type of study carried out in the reviewed works; $83.3 \%$ of the studies are cross-sectional, which is equivalent to 20 of the papers under review, while only four works are longitudinal, with a participation of 16.7\%. Among the cross-sectional studies is Galvão et al. (2019). Their field work was deployed in 2017 and examined the factors influencing students' corporate social responsibility orientation in higher education contexts. They collected primary data through questionnaires distributed to 317 undergraduate and graduate students at the "University of Trás-os-Montes and Alto Douro", a public institution in northern Portugal. Likewise, Teixeira, Ferreira, Correia and Lima (2018) carried out a cross-sectional study at the School of Administration and Technology of the largest public polytechnic in Portugal, with around 18,500 students, between March and April 2016. There they applied online surveys and obtained a resulting sample of 194 responses. They deployed various analyzes such as t-test, exploratory/confirmatory factor analysis, and MANOVA.

On the other hand, longitudinal research has less participation in the RLS (16.7\%). This type of research is relevant, for example, to understand the influence of policies of higher education institutions in guiding students' corporate social responsibility. Smith et al. (2018) provided results from the first year of research evaluating the introduction of SR content in courses for undergraduates at three universities: Colorado School of Mines, Virginia Tech, and Marietta College. They analyzed responses from surveys before and after introducing the RS content which was applied to more than 600 students in mining engineering, petroleum engineering, design, and liberal arts courses. They analyzed possible changes in students' knowledge, attitudes, and skills about SR and its relationship to engineering.

\section{- Instrument}

Table 4 summarizes the type of instrument used in the reviewed studies.

\begin{tabular}{|l|r|r|r|}
\hline Type of instrument & Frequency & Percentage & Accumulated percentage \\
\hline Questionnaire & 19 & 79.1 & 79.1 \\
\hline Interview & 3 & 12.5 & 91.6 \\
\hline Both & 2 & 8.4 & 100 \\
\hline Total & $\mathbf{2 4}$ & $\mathbf{1 0 0}$ & \\
\hline
\end{tabular}

Table 4. Characterization of the RLS according to the type of instrument

Table 4 summarizes the instruments used for data collection in the RLS; 79.1\% of the studies used questionnaires and 12.5\% interviews; $8.4 \%$ used both instruments. Among the work that used questionnaires is that of Da Silva Junior et al. (2019) who obtained 474 valid questionnaires. Their data was analyzed through descriptive statistics and non-parametric tests. Pätäri, Arminen, Albareda, Puumalainen and Toppinen (2017) used an online questionnaire provided by Qualtrics Online Survey Software that they applied to students from three universities in Finland, Hong Kong, and Spain. Smith et al. (2018) also used questionnaires, covering more than 600 students in Mining Engineering, Petroleum Engineering, Design, and Liberal Arts. Regarding interviews, Nittala, Zephirin, Howland, Kim, Katz, and Jesiek (2018) addressed 112 university students through semi-structured interviews. Their data was coded and analyzed under a thematic analysis approach. 


\section{- Participants}

Table 5 shows the type of participants covered in the studies comprising the RLS.

\begin{tabular}{|l|r|r|r|}
\hline \multicolumn{1}{|c|}{ Participants } & Frequency & Percentage & Accumulated percentage \\
\hline Students & 22 & 91.7 & 91.7 \\
\hline Students and professors & 1 & 4.2 & 95.8 \\
\hline $\begin{array}{l}\text { Students, professors, } \\
\text { administrators, and managers }\end{array}$ & 1 & 4.2 & 100 \\
\hline Total & $\mathbf{2 4}$ & $\mathbf{1 0 0}$ & \\
\hline
\end{tabular}

Table 5. Participants in the RLS studies

Table 5 shows that $91.7 \%$ of the reviewed studies have students as participants, equivalent to 22 of the 24 studies of the RLS. Only $4.2 \%$ of the studies consider students and professors; the rest (also 4.2\%) jointly include students, professors, administrators, and managers. The high percentage of studies focused on university students $(91.7 \%)$ is a sign of the importance of ensuring the quality of their education since they will be the future professionals of society. Their actions may affect or benefit the community. For example, their socially responsible initiatives may be helpful and valuable to the broader community. Silva et al. (2018) highlight the importance of studying student commitment to SR, and they covered 792 students enrolled in management undergraduate programs. Vázquez, Lanero and Licandro (2013) and Haski-Leventhal (2013) highlight, among other aspects, the need for and importance of social awareness and favorable attitudes towards SR.

\subsubsection{Conceptual model of student commitment to SR}

Figure 2 presents the conceptual model showing the dimensions identified for the student commitment to SR, derived from the pattern discovery and grouping (see section 2.3).

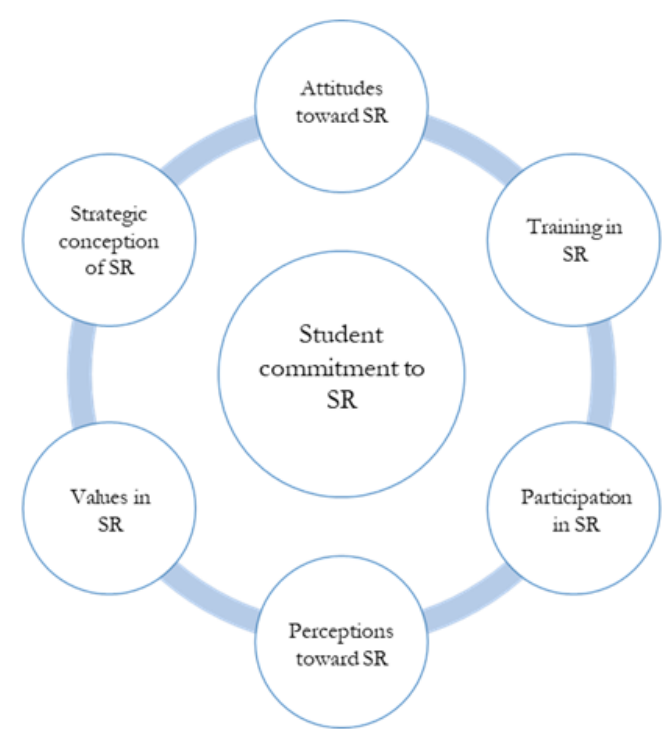

Figure 2. Model of student commitment to SR

The proposed model (Figure 2) comprises six dimensions (training, values, participation, attitudes, strategic conception, and perceptions), which are described below:

\section{- Training in SR}

In recent years, there have been drastic changes in all areas and spheres in humanity, and education has been no exception. Economic, political, and social problems have led governments and universities to reflect and seek solutions to the issue. Given that university students will be the professionals of tomorrow and their actions will be decisive for society, the university must foster training with high social, environmental, and sustainability content. The analyzed studies show different facets in university students concerning SR (Vázquez et al., 2016). For example, students learn ethics lessons in their life (Nittala et al., 2018); students project themselves as suitable future professionals committed to SR (Da Silva et al., 2019), students understand the importance of 
studying SR and sustainability (Zizka, 2017), they are willing to continue acquiring knowledge on the subject (Reis et al., 2015), and students consider that their training in ethics and citizenship is determinant forbeing considered a socially responsible individual (Martínez-Usarralde et al., 2017).

\section{- Values in SR}

Around the growing demand for educated university students with a social conscience, trained in ethical aspects, and committed to their environment to address economic, political, and social problems, values are fundamental to this transformation process. The studies show that young people currently show high personal, ethical, and moral values (Galvão et al., 2019). Furthermore, students believe that their parents' values have been fundamental in their lives (Nittala et al., 2018). Some students assume religion as the basis of their training (Nittala et al., 2018) and consider their values as a clear commitment to SR (Pätäri at al., 2017). Also, they are aware of the damages that a bad performance on their part can generate in society (Lin \& Loui, 2017). In addition, it has been reported that women tend to value ethical and social responsibilities more than men (HaskiLeventhal et al., 2017).

\section{- Participation in SR}

The university should train upright professionals for society, which expects the best from them. This dimension refers to the participation of students in initiatives related to SR. The reviewed studies report actions such as the following: (a) participation in the creation of policies that promote human, fair, and sustainable development (Vallaeys \& Álvarez Rodríguez, 2018); (b) support for philanthropic, ethical, and social awareness initiatives (Furrer et al., 2010); (c) the incorporation of best SR practices in work activities (Pätäri et al., 2017); and (d) solidarity regarding environmental concerns and the well-being of others (Teixeira et al., 2018). Interpreting this dimension in the light of Sahu (2020), the different academic actors, including students, are essential parts informing the institutional working groups oriented to plan and deploy initiatives to face the crisis generated by COVID-19.

\section{- Attitudes toward SR}

Social and environmental problems such as global warming, scarcity of resources, social conflicts, and other situations that afflict society has led universities to strive to create awareness in students about the concerns/needs of the environment that make up and of the community to which they are owed. Recent studies highlight the importance of students assuming beliefs, thoughts, feelings, and predispositions in general that are favorable towards SR issues, such as greater concern and disposition to sustainability (Berényi \& Deutsch, 2017; Larrán et al., 2018). The role of favorable attitudes towards SR is transcendental since these are determinants of future behaviors in students in the face of the individual or organizational challenges they face in their academic studies, work, and family practice.

\section{- Strategic conception of SR}

The sustainability of organizations requires a close relationship with the environment in the context of globalization. Organizations must work on a long-term strategic direction that considers incorporating practices that make them more friendly to the environment and society in general (Da Silva et al., 2019). The reviewed studies recognize the importance of organizations committing resources in favor of humanity (Teixeira et al., 2018). Thus, the teaching-learning processes must stimulate a strategic conception of SR in students; that is, students must recognize SR as a key and long-term organizational mechanism that must be planned, deployed, and controlled in the organization (Reis et al., 2015). This need demands, for example, generating spaces for discussion on SR in line with concepts, methods, and situations of strategic organizational reflection, considering the different organization stakeholders (Larrán et al., 2018; Smith et al, 2018) and the value of SR as a management tool (Berényi \& Deutsch, 2017). 


\section{- Perceptions toward SR}

Based on the Cambridge Dictionary (2016), perceptions refer to beliefs or generally held opinions about a particular tangible or intangible object, based on "how things appear". The university should help to integrally train professionals. This also includes the promotion of healthy beliefs/opinions towards SR matters. Recent studies show that students with favorable perceptions about SR improve their participation and satisfaction in SR activities (Burga et al., 2017). They manifest a greater degree of awareness towards caring for the environment (Sánchez \& Mainardes, 2016), understand the importance of studying SR (Smith et al., 2018), show positive attitudes towards sustainability (Teixeira et al., 2018), and manifest determination towards SR environmental initiatives (Burga et al., 2017; Galvão et al., 2019). In addition, they present a greater degree of awareness towards the implementation of SR initiatives (Maurice et al., 2016; Pätäri et al., 2017). Moreover, SR is perceived as a determinant of student satisfaction in the university training process (Vásquez \& Lanero, 2016).

Regarding the descriptions of the proposed dimensions and considering them as a whole that configures the student commitment to SR, our multidimensional model encourages students (and future graduates, employees, and organizational leaders) to have a complete picture of the meaning, composition, and implications of the commitment to SR. Besides, this comprehensive understanding stimulates a better decision-making process around the issue.

\subsubsection{Characterizing the RLS using the proposed model}

Figure 3 shows a bar plot summarizing the participation of the proposed dimensions in the RLS under review.

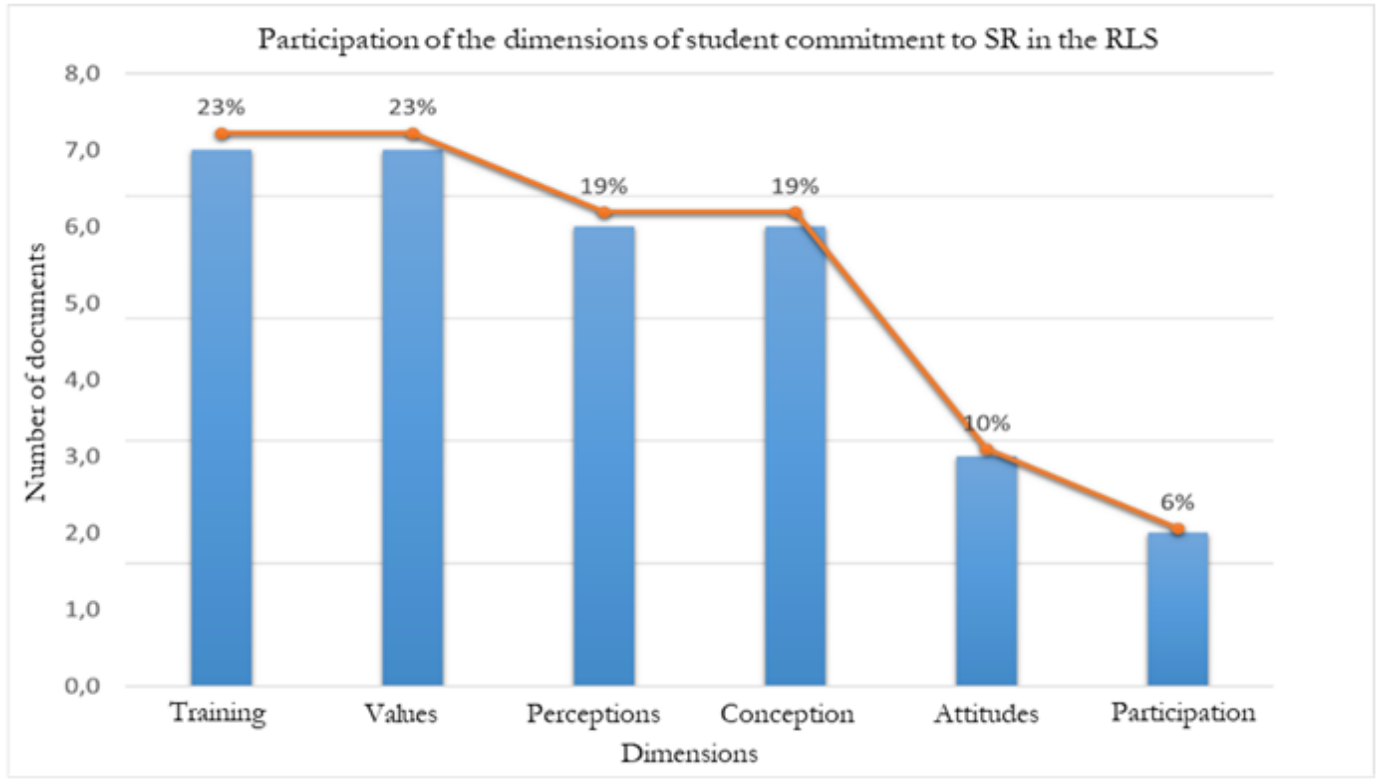

Figure 3. Percentage of participation of the dimensions of the proposed model in the RLS

Figure 3 shows that no dimension of student commitment to SR has preponderant participation in RLS. The highest participation only reached 23\%, and the dimensions of training in SR and values in SR are present in $46 \%$ of the RLS. These results support the multidimensional value of the construct because no one dimension was close to or greater than $50 \%$ of participation in the reviewed works. In other words, although SR training and values are necessary to understand the student commitment to SR, they are not sufficient for a comprehensive understanding of this complex construct. These results also are consistent with the high diversity of positions and little consensus in the literature on the subject. However, this article has collected, homologated, and synthesized empirical manifestations of the interest construct using a comprehensive model comprising six accessible latent patterns. 
Students will be future professionals, and if an organization incorporates best practices in RS within their management efforts, it will be well perceived by the students. Training in social, environmental, and sustainability content is an essential part of social commitment relevant for students. Universities should strive to include SR training processes in all their programs. Students trained in values and ethics and committed to the environment's needs can help address economic, political, and social problems. The long-term strategic direction should attend SR issues, such as investing in environmentally friendly practices and sustainability in general. Attitude towards SR is another essential issue since the increase in social awareness of current problems leads students to consider this variable as a critical factor in today's organizations. Their attitude and willingness to participate in SR initiatives and reflections make students more aware of their role in society. It is a way to contribute to facing the scourges that afflict humanity. Likewise, participation in RS by students is essential, considering the opportunities to integrate work teams strengthened by good practices, agreements, volunteering, and RS social work.

\subsubsection{Empirical manifestations of student commitment to SR}

\section{- Item formulation}

In this section, the conceptual model is operationalized through a set of manifestations proposed for each dimension (possible items derived from the interpretation and synthesis of groups of critical incidents; see section 2.3). These manifestations give rise to an initial instrument to explore the construct of interest. Table 5 provides the operationalization (make measurable) of the dimension "attitude towards SR".

\begin{tabular}{|c|c|}
\hline A.Manifestations (proposed items) & Reference works \\
\hline Indicate how interested you are in being part of & \multirow{7}{*}{$\begin{array}{l}\text { Greater concern towards } \\
\text { sustainability (Larrán et } \\
\text { al., 2018) } \\
\text { Consistency with } \\
\text { sustainability (Berényi \& } \\
\text { Deutsch, 2017) } \\
\text { Greater concern towards } \\
\text { SR (Larrán, et l., 2018) } \\
\text { Positive attitudes towards } \\
\text { SR (Silva et al., 2018) }\end{array}$} \\
\hline A.1. Organizations that are concerned about the social needs of vulnerable communities. & \\
\hline $\begin{array}{l}\text { A.2. Organizations that ensure care for the environment in the process of creating goods } \\
\text { and/or services. }\end{array}$ & \\
\hline $\begin{array}{l}\text { A.3. Organizations that show efforts to satisfy the economic objectives established by their } \\
\text { owners and/or shareholders. }\end{array}$ & \\
\hline $\begin{array}{l}\text { My main concerns about what to face in my professional life are those organizational } \\
\text { actions that put the following at risk: }\end{array}$ & \\
\hline A.4. The conservation of the environment (fauna, flora, etc.) & \\
\hline TO 5. The financial sustainability of the company & \\
\hline
\end{tabular}

Table 5. Possible manifestations of the "attitude towards SR"

Table 6 shows the statements and items proposed to make the dimension "Strategic conception of SR" measurable.

\begin{tabular}{|c|c|}
\hline B. Manifestations (proposed items) & Reference works \\
\hline $\begin{array}{l}\text { Seeing yourself as a leader of a particular company, how } \\
\text { important is the following for you: }\end{array}$ & \multirow{6}{*}{$\begin{array}{l}\text { The student commits his resources in favor of society and } \\
\text { the environment (Teixeira et al., 2018). Ideal future } \\
\text { professional with a determined attitude to act, taking into } \\
\text { account the stakeholders (Silva et al., 2018). He defends } \\
\text { the need for strategic planning in SR (Reis et al., 2015). } \\
\text { Understand the importance of generating discussion in SR } \\
\text { (Reis et al., 2015). He/she considers his/her relationship } \\
\text { with stakeholders important (Smith et al., 2018). It } \\
\text { recognizes SR as a business tool (Berényi \& Deutsch, } \\
\text { 2017). The student believes that well-managed companies } \\
\text { are socially and environmentally committed and are } \\
\text { transparent and responsible with society (Larrán et al., } \\
\text { 2018). As a future manager, the student considers } \\
\text { corporate SR as a key to business success (Alonso- } \\
\text { Almeida et al., 2015). }\end{array}$} \\
\hline $\begin{array}{l}\text { B.1. Allocate economic resources of the organization in favor } \\
\text { of vulnerable communities. }\end{array}$ & \\
\hline cial responsibility in the strategic plan of the & \\
\hline $\begin{array}{l}\text { B.3. Allocate economic resources of the organization in favor } \\
\text { of caring for the environment }\end{array}$ & \\
\hline $\begin{array}{l}\text { B.4. Include stakeholders (customers, employees, ...) to design } \\
\text { development plans for the organization }\end{array}$ & \\
\hline bility strategies to meet the needs of & \\
\hline
\end{tabular}

Table 6. Possible manifestations of the "strategic conception of SR"

Table 7 describes the statements and items proposed to make the dimension "Training in SR" measurable. 
C. Manifestations (proposed items)

Considering your current training process and aspects related to your professional projection, how important is the following for you:

C1. Spend time studying issues related to social responsibility.

C2. Invest efforts in learning aspects related to sustainability.

C3. Delve into aspects related to the environment.

C4. Deepen the study of ethics and citizenship.

\section{Reference works}

Contents of RS. (Vázquez et al., 2016). Ethics lessons in his life. (Nittala et al., 2018). The student is convinced of the importance of studying RS and sustainability. (Zizka, 2017). Shows willingness to acquire knowledge (Reis et al., (2015). The female gender values RS education more (Haski-Leventhal, Roza \& Meijs, 2015). Training in ethics and citizenship lead student to be socially responsible (Martínez-Usarralde et al., 2017) Ideal future professional committed to SR (Da Silva et al., 2019).

Table 7. Possible manifestations of "Training in SR"

In Table 8, the statements and items proposed for the dimension "participation in SR" are established.

\begin{tabular}{|l|l|}
\hline D. Manifestations (proposed items) & \multicolumn{1}{c|}{ Reference works } \\
\hline $\begin{array}{l}\text { Projecting yourself as a business leader, how important is } \\
\text { it for you to dedicate time, resources, and effort to the } \\
\text { following: }\end{array}$ & $\begin{array}{l}\text { The student expresses acceptance to promote innovation } \\
\text { (Belyaeva et al., 2018). Participate in developing policies } \\
\text { that promote more just and humane development, } \\
\text { Incorporate good SR practices (Vallaeys \& Álvarez } \\
\text { Dodríguez, 2019). As an intrapreneur, student applies SR } \\
\text { strategies in his work (Sánchez \& Mainardes, 2016). }\end{array}$ \\
\cline { 1 - 1 } $\begin{array}{l}\text { D2.Participate in the creation of business policies for human } \\
\text { development }\end{array}$ & $\begin{array}{l}\text { Student manifests himself/herself as committed to } \\
\text { fostering economic development by incorporating best } \\
\text { SR practices in its context (Vallaeys \& Álvarez Rodríguez, } \\
\text { 2019) }\end{array}$ \\
\hline D3. Incorporate good business practices of social responsibiling
\end{tabular}

Table 8. Possible manifestations of "participation in SR"

Table 9 shows the statements and items proposed for the dimension "perception towards SR".

\section{E. Manifestations (proposed items)}

How much do you agree with the following aspects? E1. Social responsibility helps improve employee engagement with the company

E2. Social responsibility generates a greater degree of awareness towards caring for the environment

E3. Investing in social responsibility favors company performance

E4. The study of social responsibility increases the degree of commitment to the social problems of humanity

E5. Social responsibility is a useful strategy to achieve sustainability (economic, ecological and social)

\section{Reference works}

Recognizing SR improves participation and satisfaction in related activities (Burga et al., 2017). A greater degree of awareness towards caring for the environment (Sánchez \& Mainardes, 2016). Values and commitment towards SR are essential factors for a better environmental performance of the forest industry (Burga et al., 2017). Understand the importance of studying SR (Smith et al., 2018). The student manifests a greater degree of awareness towards the implementation of the SR (Maurice et al., 2016). The student shows positive perceptions towards sustainability (Teixeira et al., 2018). The student shows positive perceptions towards SR strategies and is aware of the importance of SR (Galvão et al., 2019). Greater awareness towards SR (Pätäri et al., 2017). Student perceives that SR is determinant for satisfaction with the training process (Vásquez \& Llanero., 2016)

Table 9. Possible manifestations of the "perception towards SR" 
Table 10 describes the statements and items proposed for the dimension "Values in SR".

\begin{tabular}{|c|c|}
\hline F. Manifestations (proposed items) & Reference works \\
\hline $\begin{array}{l}\text { How important do you consider the following in achieving } \\
\text { your career goals: }\end{array}$ & \multirow{7}{*}{$\begin{array}{l}\text { The female gender values ethical issues (Haski- } \\
\text { Leventhal et al., 2017). The student manifests himself as } \\
\text { a being with deep personal values, ethics, and morals } \\
\text { (Galvão et al., 2019). He considers that training in his } \\
\text { parents' values is fundamental in his life (Nittala et al., } \\
\text { 2018). He assumes religion as the basis of his formation } \\
\text { (Nittala et al., 2018). The student considers his values as } \\
\text { a commitment to social responsibility (Pätäri et al., } \\
\text { 2017). He is aware of the damage that bad behavior can } \\
\text { cause to society (Lin, \& Loui, 2017). Students' values on } \\
\text { SR in the forest industry (Pätäri et al. (2017). Concern } \\
\text { for philanthropic and ethical aspects and a greater } \\
\text { degree of social awareness (Silva et al., 2018). Considers } \\
\text { that solidarity, quality of life, environmental concerns, } \\
\text { well-being, and concern for others are important issues } \\
\text { (Teixeira et al., 2018) }\end{array}$} \\
\hline F1. Incorporate social responsibility into business strategy & \\
\hline F2. Personal values, ethics, and moral & \\
\hline F3. Training in social responsibility & \\
\hline F4. Support for vulnerable communities & \\
\hline F5. Behaviors that help protect the environment & \\
\hline F6. The instruction in values that my parents instilled in me & \\
\hline
\end{tabular}

Table 10. Possible manifestations of "Values in SR"

\section{- Content validation}

This section consists of two sections. The first describes the basic information about the experts who served as validators of the proposed instrument. The second synthesizes the results of this validation, considering the clarity and relevance of the items.

\section{Sociodemographic characterization of the expert group:}

Table 11 shows the gender, academic training, and current profession of each of the evaluators.

The respondents are qualified people with a high degree of work experience and academic status, and all of them work in universities.

Following what was stated in section 2.3, each evaluator was asked to rate the relevance and clarity of each of the items of the proposed dimensions, using a score between 1 (very low/little clarity/relevance) and 5 (very high). Both of the qualifications under the described score and the narrative observations reflected in an additional (open) question which was essential to obtain a reasonable panorama about the degree to which the instrument covers the important content of the construct under study.

\begin{tabular}{|l|l|l|l|l|}
\hline Expert & Gender & Undergraduate & Postgraduate & Current profession \\
\hline E1 & M & Industrial engineering & Master's degree & Professor \\
\hline E2 & F & Chemical engineering & Doctor & Professor \\
\hline E3 & M & Speech Therapy & Master's degree & Professor \\
\hline E4 & M & Sanitary Engineering & Doctorate & Professor \\
\hline E5 & M & Electric engineering & Master's degree & Professor \\
\hline E6 & F & Business Administration & Master's degree & Professor \\
\hline E7 & M & Systems engineer & Master's degree & Manager \\
\hline E8 & M & Production Engineering & Master's degree & Professor \\
\hline E9 & F & Business Administration & Master's degree & Professor \\
\hline E10 & M & Civil Engineering & Doctorate & Professor \\
\hline
\end{tabular}

Table 11. General information of the experts

\section{Clarity and relevance of the items}

Next, the numerical results of the content validation are presented, together with their respective descriptions. All of this is reflected by segmenting according to the dimension of the proposed conceptual model.

Attitude towards SR 
Table 12 presents the summary of the relevance and clarity ratings issued by the evaluators to the items of the dimension "Attitude towards SR".

\begin{tabular}{|c|c|c|c|c|c|c|c|c|}
\hline \multirow{2}{*}{ Items } & \multicolumn{4}{|c|}{ Relevance } & \multicolumn{4}{|c|}{ Clarity } \\
\hline & Minimum & Mean & SD & VC & Minimum & Mean & SD & VC \\
\hline A1 & 3 & 4.70 & .675 & $14.4 \%$ & 4 & 4.90 & .316 & $6.5 \%$ \\
\hline A2 & 4 & 4.90 & .316 & $6.5 \%$ & 5 & 5.00 & .000 & $0.0 \%$ \\
\hline A3 & 2 & 4.00 & 1.414 & $35.4 \%$ & 5 & 5.00 & .000 & $0.0 \%$ \\
\hline A4 & 4 & 4.90 & .316 & $6.5 \%$ & 4 & 4.90 & .316 & $6.5 \%$ \\
\hline A5 & 3 & 4.50 & .707 & $15.7 \%$ & 4 & 4.80 & .422 & $8.8 \%$ \\
\hline A6 & 4 & 4.80 & .422 & $8.8 \%$ & 4 & 4.80 & .422 & $8.8 \%$ \\
\hline
\end{tabular}

SD: Standard deviation; VC: Variation Coefficient

Table 12. Descriptive statistics for the attitude towards SR items

Table 12 shows that all of the "attitude towards SR" items reflect a favorable perception in terms of relevance (means greater than 4.0) and clarity (means greater than 4.5). In "relevance", the minimum value obtained was 2.0 (AR3), followed by values greater or equal than 3.0 " with coefficients of variation lower than $16 \%$, except for AR3 (35.4\%). Regarding the clarity of the items, the scores of the ten experts were even more favorable with minimum values of 4.0, averages between 4.8 and 5.0, and low coefficients of variation (maximum 8.8\%).

Thus, the validation of the content of the items about "attitude towards SR" only motivates the review of the relevance of item AR3 ("organizations that strive to satisfy the economic objectives established by their owners and/or shareholders," minimum value less than 3). Specifically, three of the ten experts rated this item at 2.0, deducing a perception of low relevance of the item. However, the remaining seven experts considered AR3 as relevant (six of them rating it with 5 points and the other with 4). Moreover, considering that SR aims to attend to the environment, employees, and external stakeholders, and since it promulgates attention to owners and/or shareholders' needs/expectations, we decided to conserve this item.

In summary, the dimension "attitude towards SR", proposed in the conceptual model (see Figure 2) and operationalized using six items tested, has obtained exploratory evidence in favor of its content validity.

Strategic Conception of the RS

Table 13 shows the ratings of the relevance and clarity items issued by the evaluators regarding the content of the dimension "Strategic Conception of SR".

\begin{tabular}{|c|c|r|r|r|r|r|r|r|r|}
\hline \multirow{2}{*}{ Items } & \multicolumn{4}{|c|}{ Relevance } & \multicolumn{4}{c|}{ Clarity } \\
\cline { 2 - 10 } & Minimum & Mean & \multicolumn{1}{c|}{ SD } & \multicolumn{1}{c|}{ VC } & Minimum & Mean & \multicolumn{1}{c|}{ SD } & \multicolumn{1}{c|}{ VC } \\
\hline B1 & 3 & 4.60 & .843 & $18.3 \%$ & 4 & 4.80 & .422 & $8.8 \%$ \\
\hline B2 & 4 & 4.80 & .422 & $8.8 \%$ & 5 & 5.00 & .000 & $0.0 \%$ \\
\hline B3 & 3 & 4.70 & .675 & $14.4 \%$ & 4 & 4.90 & .316 & $6.5 \%$ \\
\hline B4 & 4 & 4.90 & .316 & $6.5 \%$ & 4 & 4.90 & .316 & $6.5 \%$ \\
\hline B5 & 4 & 4.80 & .422 & $8.8 \%$ & 4 & 4.90 & .316 & $6.5 \%$ \\
\hline
\end{tabular}

SD: Standard deviation; VC: Variation Coefficient

Table 13. Descriptive statistics for the items of Strategic Conception of the SR

Table 13 shows that all of the "strategic conception of SR" items show a high favorability towards relevance and clarity. For example, in "relevance", the mean value was 4.60 (BR1) followed by higher values with coefficients of variation lower or equal than $18.3 \%$. Regarding the clarity of the items, the scores expressed by the evaluators were even more favorable with minimum values of 4.0, averages between 4.8 and 5.0, and low coefficients of variation (maximum $8.8 \%$ ).

Thus, the dimension "strategic conception of SR", proposed in the conceptual model and operationalized through 5 items, has obtained exploratory evidence in favor of its content validity. 


\section{Training in $\mathrm{RS}$}

Table 14 shows the relevance and clarity ratings issued by the evaluators to each of the items proposed for "Training in SR".

\begin{tabular}{|c|r|r|r|r|r|r|r|r|r|}
\hline \multirow{2}{*}{ Items } & \multicolumn{4}{|c|}{ Relevance } & \multicolumn{4}{c|}{ Clarity } \\
\cline { 2 - 10 } & Minimum & Mean & SD & VC & & Minimum & Mean & \multicolumn{1}{c|}{ SD } & \multicolumn{1}{c|}{ VC } \\
\hline C1 & 4.00 & 4.80 & 0.42 & $8.78 \%$ & 4.00 & 4.90 & 0.32 & $6.45 \%$ \\
\hline C2 & 3.00 & 4.70 & 0.67 & $14.36 \%$ & 4.00 & 4.90 & 0.32 & $6.45 \%$ \\
\hline C3 & 3.00 & 4.70 & 0.67 & $14.36 \%$ & 3.00 & 4.80 & 0.63 & $13.18 \%$ \\
\hline C4 & 4.00 & 4.80 & 0.42 & $8.78 \%$ & 4.00 & 4.90 & 0.32 & $6.45 \%$ \\
\hline
\end{tabular}

SD: Standard deviation; VC: Variation Coefficient

Table 14. Descriptive statistics for SR Training items

Table 14 shows that all of the "training in SR" items reflect a favorable perception of the properties of interest. In "relevance", the minimum value obtained was 3.0 (C2 and C3), and the mean values ranged between 4.7 and 4.8 with coefficients of variation lower or equal than $14.36 \%$. Regarding clarity, the evaluators' scores were much more favorable with a single minimum value of 3.0, averages between 4.8 and 4.9, and low coefficients of variation (maximum 13.18\% ). This supports the content validity of the dimension under consideration.

Participation in RS

Table 15 summarizes the relevance and clarity ratings for the dimension "Participation in SR".

\begin{tabular}{|r|r|r|r|r|r|r|r|r|r|}
\hline \multirow{2}{*}{ Items } & \multicolumn{4}{|c|}{ Relevance } & \multicolumn{1}{|c|}{ Clarity } \\
\cline { 2 - 10 } & Minimum & Mean & SD & VC & Minimum & Mean & \multicolumn{1}{c|}{ SD } & \multicolumn{1}{c|}{ VC } \\
\hline D1 & 2.00 & 4.30 & 1.06 & $25 \%$ & 2.00 & 4.70 & 0.95 & $20 \%$ \\
\hline D2 & 4.00 & 4.90 & 0.32 & $6 \%$ & 5.00 & 5.00 & 0.0 & $0 \%$ \\
\hline D3 & 4.00 & 4.80 & 0.42 & $9 \%$ & 4.00 & 4.90 & 0.32 & $6 \%$ \\
\hline D4 & 3.00 & 4.60 & 0.70 & $15 \%$ & 2.00 & 4.50 & 1.08 & $24 \%$ \\
\hline D5 & 3.00 & 4.50 & 0.71 & $16 \%$ & 4.00 & 4.80 & 0.42 & $9 \%$ \\
\hline
\end{tabular}

SD: Standard deviation; VC: Variation Coefficient

Table 15. Descriptive statistics for the items of Participation in SR

Table 15 reveals that the items also reflect a favorable perception in terms of relevance and clarity. Regarding "relevance", even though all of the items presented mean values higher than 4.0, one obtained a minimum value of 2.0. For this reason, D1 ("Meetings to promote business social innovation") was reviewed. Specifically, one of the experts gave a score of 2.0 to this item. However, the remaining nine scored 4.0 or 5.0. When we examined the observations for the score of 2.0, no reasons were found that questioned the position of the other nine experts and merited the exclusion/modification of the item. Therefore, the item was preserved without changes. The same happened in the case of item D4 ("promote business economic development") in the "clarity" property.

The dimension "Participation in SR" obtained exploratory evidence in favor of its content validity.

Perception towards SR

Table 16 shows the summary of the relevance and clarity ratings issued by the evaluators for the dimension "Perception of SR". 


\begin{tabular}{|c|c|c|c|c|c|c|c|c|}
\hline \multirow[t]{2}{*}{ Items } & \multicolumn{4}{|c|}{ Relevance } & \multicolumn{4}{|c|}{ Clarity } \\
\hline & Minimum & Mean & SD & VC & Minimum & Mean & SD & VC \\
\hline E1 & 4.00 & 4.80 & 0.42 & $9 \%$ & 5.00 & 5.00 & 0.0 & $0 \%$ \\
\hline E2 & 3.00 & 4.70 & 0.67 & $14 \%$ & 3.00 & 4.80 & 0.63 & $13 \%$ \\
\hline E3 & 4.00 & 4.50 & 0.53 & $12 \%$ & 3.00 & 4.70 & 0.67 & $14 \%$ \\
\hline E4 & 3.00 & 4.00 & 1.56 & $39 \%$ & 3.00 & 4.60 & 0.70 & $15 \%$ \\
\hline E5 & 3.00 & 4.40 & 0.84 & $19 \%$ & 4.00 & 4.80 & 0.42 & $9 \%$ \\
\hline
\end{tabular}

SD: Standard deviation; VC: Variation Coefficient

Table 16. Descriptive statistics for the items of "Perception towards SR"

Table 16 shows that all the items of "perception towards SR" reflect a favorable perception of the items' relevance and clarity. In the five items and the two properties, the minimum score was 3.0, and the average values were at least 4.0; in "relevance", they ranged between 4.0 and 4.8 and in clarity between 4.6 and 5.0. These results exploratorily favor the content validity of the dimension in the study.

Values towards RS

Table 17 presents the summary of the relevance and clarity ratings for the dimension "SR Values".

\begin{tabular}{|l|r|r|r|r|r|r|r|r|r|}
\hline \multirow{2}{*}{ Items } & \multicolumn{4}{|c|}{ Relevance } & \multicolumn{4}{|c|}{ Clarity } \\
\cline { 2 - 10 } & Minimum & Mean & \multicolumn{1}{|c|}{ SD } & \multicolumn{1}{c|}{ VC } & Minimum & Mean & \multicolumn{1}{c|}{ SD } & \multicolumn{1}{c|}{ VC } \\
\hline F1 & 2.00 & 4.14 & 1.21 & $29 \%$ & 2.00 & 4.63 & 1.06 & $23 \%$ \\
\hline F2 & 5.00 & 5.00 & 0 & $0 \%$ & 5.00 & 5.00 & 0 & $0 \%$ \\
\hline F3 & 4.00 & 4.89 & 0.33 & $7 \%$ & 4.00 & 4.89 & 0.33 & $7 \%$ \\
\hline F4 & 4.00 & 4.89 & 0.33 & $7 \%$ & 5.00 & 5.00 & 0 & $0 \%$ \\
\hline F5 & 4.00 & 4.88 & 0.35 & $7 \%$ & 5.00 & 5.00 & 0 & $0 \%$ \\
\hline F6 & 3.00 & 4.57 & 0.79 & $17 \%$ & 3.00 & 4.63 & 0.74 & $16 \%$ \\
\hline
\end{tabular}

SD: Standard deviation; VC: Variation Coefficient

Table 17. Descriptive statistics for the "SR values" items

Table 17 shows that the total of the items of "values towards SR" presents a favorable average score towards relevance (greater than 4.1) and clarity (greater than 4.6). However, in item F1 ("incorporating the SR into the business strategy"), one of the ten evaluators assigned a rating of "2" to both properties. When investigating this, we did not find sufficient reasons to contradict the position taken by the other evaluators. These results, coupled with mean values of 4.14 and 4.63 in relevance and clarity, led to keeping the item. In summary, the evidence suggests that the six items under observation, arising from the literature that make up the RLS and analyzed from the perspective of clarity and relevance, satisfy the content validity for the dimension "SR Values".

\section{Conclusions}

This study carries out a systematic review of the literature on the manifestations of the student commitment to SR, extracted from the 24 works that defined the RLS. From the analysis of grouping patterns of such manifestations, a comprehensive conceptual model is proposed that consists of six dimensions which reasonably summarize the manifestations of the student commitment to SR.

Additionally, these manifestations were made measurable using 32 items that satisfy clarity and relevance properties, as demonstrated by the content validation carried out. The RLS is characterized from this model, which allowed us to identify the main focal areas of research today and the dimensions less addressed by the literature.

This work has provided answers to the knowledge gap about the extraction, homogenization, grouping, and synthesis of the available evidence regarding the manifestations of the student commitment to SR by using a systematic review of the literature with critical incidents and agreement between judges.

This article has shown that the content of student commitment to SR is multidimensional, configured in six observable/measurable and interrelated dimensions. These dimensions broaden the understanding of the subject and facilitate the demolition of merely altruistic and/or fragmented thoughts, perceptions, and meanings about SR, which are usually detached from the multidimensionality of the human beings and organizational routines. 
For this reason, this study draws attention to the need for educational institutions and students (as co-producers of their training) to carry out comprehensive management efforts to assume proactive positions regarding how, throughout the training process, they will ensure the six facets revealed in this work (e.g., development of knowledge about SR, strategic conceptions of SR, ...). The proposed model and instrument make it possible to strengthen or renew the ways of thinking of leaders and students about the integrality of a genuine commitment to SR.

This article provides valuable insights to help embed the development and measurement of such a commitment within the training curriculum in educational institutions. This challenge is available to be achieved using the discovered facets because these are consistent with educational management approaches centered on being (e.g., values, attitudes, perceptions alluding to SR), knowing (SR training, SR strategic conception), and doing (participation in SR initiatives). From this perspective, leaders are encouraged to identify relevant alternatives to focus efforts and resources in favor of the student commitment to SR and the social, economic, and environmental impacts derived from it.

\section{Limitations}

The articles under review were located through Scopus, which is considered the database with the largest number of abstracts and scientific citations worldwide. Other possible articles on the subject published by journals not indexed in Scopus may have been left out. However, considering bibliometric studies of comparison between Scopus and other databases (e.g., Bergman, 2012) and taking into account areas related to the organization management, it is expected that the number of potentially relevant articles not considered is reduced. Future works could replicate the present study using other databases such as Web of Science.

The inclusion of studies considered the primary language of science (English). Twenty-two articles are published in English, and the remaining two articles are in Spanish (the authors' native language). While this ensures broad coverage of scientific papers, other possibly relevant papers on student commitment to SR, written in other languages, were not considered.

\section{Future work}

Extend the conceptual model considering additional constructs that act as antecedents or consequences of the studied commitment and make it possible to formulate argued propositions to be contrasted in empirical works. Psychometrically validate the proposed instrument through its application in massive samples that help to reveal the levels of reliability, internal validity, and external validity of the instrument.

\section{Declaration of Conflicting Interests}

The author declared no potential conflicts of interest with respect to the research, authorship, and/or publication of this article.

\section{Funding}

The authors received no financial support for the research, authorship, and/or publication of this article.

\section{References}

Albliwi, S.A., Antony, J., \& Lim, S.A.H. (2015). A systematic review of Lean Six Sigma for the manufacturing industry. Business Process Management Journal, 21(3), 665-691. https://doi.org/10.1108/BPMJ-03-2014-0019

Alonso-Almeida, M.D.M., Fernández de Navarrete, F.C., \& Rodriguez-Pomeda, J. (2015). Corporate social responsibility perception in business students as future managers: A multifactorial analysis. Business Etbics: A European Review, 24(1), 1-17. https://doi.org/10.1111/beer.12060

Bass, B.M., Avolio, B.J., Jung, D.I., \& Berson, Y. (2003). Predicting unit performance by assessing transformational and transactional leadership. Journal of applied psychology, 88(2), 207-218. 
Bhattacharyya, A., \& Rahman, M.L. (2020). Values, gender and attitudes towards environmental policy: A study of future managers. Business Strategy and the Environment, 29(6), 2514-2527.

https://doi.org/10.1002/bse.2517

Belyaeva, Z., Scagnelli, S.D., Thomas, M., \& Cisi, M. (2018). Student perceptions of university social responsibility: implications from an empirical study in France, Italy and Russia. World Review of Entrepreneurship, Management and Sustainable Development, 14(1-2), 23-42. https://doi.org/10.1504/WREMSD.2018.089094

Berényi, L., \& Deutsch, N. (2017). Gender differences in attitudes to corporate social responsibility among Hungarian business students. Wseas Transactions on Business and Economic, 14, 298-310.

Bergman, E.M.L. (2012). Finding citations to social work literature: The relative benefits of using Web of Science, Scopus, or Google Scholar. The journal of academic librarianship, 38(6), 370-379. https://doi.org/10.1016/j.acalib.2012.08.002

Beyene, K.A., Sheridan, J., \& Aspden, T. (2014). Prescription medication sharing: A systematic review of the literature. American journal of public health, 104(4), e15-e26. https://doi.org/10.2105/AJPH.2013.301823

Blowfield, M., \& Frynas, J.G. (2005). Editorial Setting new agendas: Critical perspectives on Corporate Social Responsibility in the developing world. International affairs, 81(3), 499-513. https://doi.org/10.1111/j.14682346.2005.00465.x

Burga, R., Leblanc, J., \& Rezania, D. (2017). Analysing the effects of teaching approach on engagement, satisfaction and future time perspective among students in a course on CSR. The International Journal of Management Education, 15(2), 306-317. https://doi.org/10.1016/j.ijme.2017.02.003

Cambridge Dictionary (2016). http://dictionary.cambridge.org/es/diccionario/ingles/perception. (Consulted May 22nd, 2021).

Claver-Cortés, E., Marco-Lajara, B., Úbeda-García, M., García-Lillo, F., Rienda-García, L., Zaragoza-Sáez, P. C., et al. (2020). Students' perception of CSR and its influence on business performance. A multiple mediation analysis. Business Ethics: A European Review, 29(4), 722-736. https://doi.org/10.1111/beer.12286

Da Silva Junior, A., de Oliveira Martins-Silva, P., de Araújo Vasconcelos, K.C., da Silva, V.C., de Brito, S.L.M.S., \& Monteiro, J.M.R. (2019). Sustainability and corporate social responsibility in the opinion of undergraduate students in management programs: Between the concrete and the abstract. Journal of cleaner production, 207, 600-617. https://doi.org/10.1016/j.jclepro.2018.10.011

Denyer, D., \& Tranfield, D. (2009). Producing a systematic review. In D.A. Buchanan \& A. Bryman (Eds.), The Sage handbook of organizational research methods (p. 671-689). London: Sage Publications Ltd.

ECLAC (2020). Measuring the impact of COVID-19 with a view to reactivation, Economic Commission for Latin America and Caribbean. Available online at: https://repositorio.cepal.org/bitstream/handle/11362/45477/1/

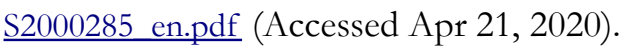

Fowler, F., Noronha, J., Rosendo, A., Ribeiro, \& Gonçalves, L. (2018). International Symposium on Project Approaches in Engineering Education. PAEE 2018 and 15th Active Learning in Engineering Education Workshop, ALE 2018; Brasilia; Brazil; 28 February 2018 through 2 March 2018; Code 216929.

Galvão, A., Mendes, L., Marques, C., \& Mascarenhas, C. (2019). Factors influencing students' corporate social responsibility orientation in higher education. Journal of cleaner production, 215, 290-304.

https://doi.org/10.1016/j.jclepro.2019.01.059

Garde Sánchez, R., Rodríguez Bolívar, M.P., \& López-Hernández, A.M. (2013). Online disclosure of university social responsibility: A comparative study of public and private US universities. Environmental Education Research, 19(6), 709-746. https://doi.org/10.1080/13504622.2012.749976

Gay, L.R. (1980). Educational Evaluation \& Measurement: Competencies for analysis and application. Columbus, Ohio: CE Merill Publishing Company. 
Haski-Leventhal, D. (2013). Employee engagement in CSR: The case of payroll giving in Australia. Corporate Social Responsibility and Environmental Management, 20(2), 113-128. https://doi.org/10.1002/csr.1287

Haski-Leventhal, D., Pournader, M., \& McKinnon, A. (2017). The role of gender and age in business students' values, CSR attitudes, and responsible management education: Learnings from the PRME international survey. Journal of Business Ethics, 146(1), 219-239. https://doi.org/10.1007/s10551-015-2936-2

Haski-Leventhal, D., Roza, L., \& Meijs, L.C. (2015). Congruence in corporate social responsibility: Connecting the identity and behavior of employers and employees. Journal of Business Ethics, 143(1), 35-51. https://doi.org/10.1007/s10551-015-2793-z

Hayes, B.E. (1995). Cómo medir la satisfacción del cliente: desarrollo y utilización de cuestionarios (No. 658.834 H417c). Barcelona: Ed. Gestión 2000.

Holland, L. (2004). Experiences from a student programme designed to examine the role of the accountant in corporate social responsibility (CSR). International Journal of Sustainability in Higher Education, 5(4), 404-416. https://doi.org/10.1108/14676370410561108

Ibe, C.M., Min, W.Z., Ling, K.C., \& Yii, D.S.K. (2015). Exploring performance based practice of CSR in sustaining the relationship between business and society: A literature review. Asian Social Science, 11(5), 181. https://doi.org/10.5539/ass.v11n5p181

Jensen, B. (2016, June). Critical Perspectives on Corporate Social Responsibility Research Methods: An Evaluation of Two Different Research Strategies and Designs. In European Conference on Research Methodology for Business and Management Studies (p. 375). Academic Conferences International Limited.

Kagitcibasi, C. (1997). Individualism and collectivism. Handbook of cross-cultural psychology, 3, 1-49.

Kim, H., \& Xie, B. (2015). Health literacy and internet-and mobile app-based health services: A systematic review of the literature. Proceedings of the Association for Information Science and Technology, 52(1), 1-4. https://doi.org/10.1002/pra2.2015.145052010075

Larrán, M., Andrades, J., \& Herrera, J. (2018). An examination of attitudes and perceptions of Spanish business and accounting students toward corporate social responsibility and sustainability themes. Revista de Contabilidad-Spanish Accounting Review, 21(2), 196-205. https://doi.org/10.1016/j.rcsar.2018.02.001

Lewis, R.L., Brown, D.A., \& Sutton, N.C. (2019). Control and empowerment as an organising paradox: Implications for management control systems. Accounting, Auditing \& Accountability Journal, 32(2), 483-507. https://doi.org/10.1108/AAAJ-11-2017-3223

Lin, A., \& Loui, M.C. (2017, October). Students' perceptions of the social responsibilities of engineers. In 2017 IEEE Frontiers in Education Conference (FIE) (pp. 1-4). IEEE. https://doi.org/10.1109/FIE.2017.8190645

Lockhart Nelson, S. (2017). Pattern and Meaning. Interalia Magazine, Retrieved from: http://uhra.herts.ac.uk/bitstream/handle/2299/19070/pattern_and_meaning_final_.pdf?sequence $=2$

Martínez-Usarralde, M.J., Lloret-Catalá, C., \& Mas-Gil, S. (2017). Responsabilidad Social Universitaria (RSU): Principios para una universidad sostenible, cooperativa y democrática desde el diagnóstico participativo de su alumnado. Education Policy Analysis Archives-EPAA, 2017, 25(75), 1-2. https://doi.org/10.14507/epaa.25.2769

Murphy, M.J., MacDonald, J.B., Antoine, G.E., \&Smolarski, J.M. (2019). Exploring muslim attitudes towards corporate social responsibility: Are Saudi business students different?. Journal of Business Ethics, 154(4), 1103-1118. https://doi.org/10.1007/s10551-016-3383-4

Nittala, S., Zephirin, T., Howland, S.M.J., Kim, M.D., Katz, A., \& Jesiek, B.K. (2018). ASEE Annual Conference and Exposition, Conference Proceedings Volume 2018-june, 23 June 2018125th ASEE Annual Conference and Exposition; Salt Palace Convention CenterSalt Lake City; United States; 23 June 2018 through 27 December 2018; Code 138114.

Parasher, M., Sharma, S., Sharma, A.K., \& Gupta, J.P. (2011). Anatomy on pattern recognition. Indian Journal of Computer Science and Engineering (IJCSE), 2(3), 371-378. 
Pätäri, S., Arminen, H., Albareda, L., Puumalainen, K., \& Toppinen, A. (2017). Student values and perceptions of corporate social responsibility in the forest industry on the road to a bioeconomy. Forestpolicy and economics, 85, 201-215. https://doi.org/10.1016/j.forpol.2017.10.009

Peisakhin, L. (2012). Transparency and corruption: Evidence from India. The Journal of Law and Economics, 55(1), 129-149. https://doi.org/10.1086/663727

Pérez-Rave, J. (2012). Revisión sistemática de literatura en ingeniería. Medellín: Sello Editorial UdeA, Medellín.

Pérez-Rave, J. (2019). Revisión sistemática de literatura en ingeniería. Ampliada y actualizada. (2a ed). Medellín: Editorial Idinnov.

Ralph, M., \& Stubbs, W. (2014). Integrating environmental sustainability into universities. Higher Education, 67(1), 71-90. https://doi.org/10.1007/s10734-013-9641-9

Reis, R., von Schwedler, M., \& Gomes, S. (2015). Corporate Social Responsibility Knowledge in Higher Education Students in Portugal. Proceedings of the European Conference on Knowledge Management, ECKM pp. 628634.

Rodríguez-Gómez, S., Garde-Sánchez, R., Arco-Castro, M.L., \& López-Pérez, M.V. (2020). Does the Use of Social Media Tools in Classrooms Increase Student Commitment to Corporate Social Responsibility?. Frontiers in Psychology, 11, 3690. https://doi.org/10.3389/fpsyg.2020.589250

Rulifson, M.G. (2015). Engineering students' varied and changing views of social responsibility. American Society for Engineering Education, 26, 1. https://doi.org/10.18260/p.23981

Sahu, P. (2020). Closure of universities due to coronavirus disease 2019 (COVID-19): Impact on education and mental health of students and academic staff. Cureus, 12(4). https://doi.org/10.7759/cureus.7541

Sánchez-Hernández, M.I., \& Mainardes, E.W. (2016). University social responsibility: A student base analysis in Brazil. International Review on Public and Nonprofit Marketing, 13(2), 151-169. https://doi.org/10.1007/s12208-0160158-7

Shaidullina, A.R., Zakirova, V.G., Kashurnikov, S.N., Arestova, E.N., Shmidt, A.N., \& Kovaleva, N.I. (2018). Students training for innovative entrepreneurial activity: Social responsibility competences. Espacios, 39(2), 15-15.

Silva Junior, A.D., Martins-Silva, P.D.O., Feu, K.S., Komino, A.C., Silva, V.C.D., \& Vasconcelos, K.C.D.A. (2018). Corporate social responsibility in the perspective of Brazilian management students: The inversion of the pyramid. Social Responsibility Journal, 16(1), 50-72. https://doi.org/10.1108/SRJ-01-2018-0013

Smith, J.M., Smith, N.M., Rulifson, G., McClelland, C.J., Battalora, L.A., Sarver, E.A. et al. (2018). Student Learning About Engineering and Corporate Social Responsibility: A Comparison Across Engineering and Liberal Arts Courses. In ASEE Annual Conference \& Exposition. https://doi.org/10.18260/1-2--31007

Teixeira, A., Ferreira, M.R., Correia, A., \& Lima, V. (2018). Students' perceptions of corporate social responsibility: Evidences from a Portuguese higher education institution. International Review on Public and Nonprofit Marketing, 15(2), 235-252. https://doi.org/10.1007/s12208-018-0199-1

Torgerson, C. (2003). Systematic reviews. New York: Bloomsbury Publishing.

Vallaeys, F., \& Álvarez Rodríguez, J. (2018). Hacia una definición latinoamericana de Responsabilidad Social Universitaria. Aproximación a las preferencias conceptuales de los universitarios. Educación XX1, 22(1), 93-116. https://doi.org/10.5944/educxx1.19442

Vallaeys, F., \& Álvarez Rodriguez, J. (2019). Towards a latin american definition of university social responsibility. approximation to the conceptual preferences of university students. EDUCACION XX1, 22(1), 93-116. https://doi.org/10.5944/educxx1.19442 
Vázquez, J.L., Aza, C.L., \& Lanero, A. (2016). University social responsibility as antecedent of students’ satisfaction. International Review on Public and Nonprofit Marketing, 13(2), 137-149. https://doi.org/10.1007/s12208016-0157-8

Vázquez, J.L., Lanero, A., \& Licandro, O. (2013). Corporate social responsibility and higher education: Uruguay university students'perceptions. Economics \& Sociology, 6(2), 145-157. https://doi.org/10.14254/2071789X.2013/6-2/13

Watkins, I., \& Xie, B. (2014). eHealth literacy interventions for older adults: A systematic review of the literature. Journal of medical Internet research, 16(11), e225. https://doi.org/10.2196/jmir.3318

Zizka, L. (2017). Student perceptions of ethics, CSR, and sustainability (ECSRS) in hospitality management education. Journal of teaching in travel \& tourism, 17(4), 254-268. https://doi.org/10.1080/15313220.2017.1399497

Intangible Capital, 2021 (www.intangiblecapital.org)

Intangible Capital, 2021 (www.intangiblecapital.org)
Article's contents are provided on an Attribution-Non Commercial 4.0 Creative commons International License. Readers are allowed to
copy, distribute and communicate article's contents, provided the author's and Intangible Capital's names are included. It must not be
used for commercial purposes. To see the complete license contents, please visit https://creativecommons.org/licenses/by-nc/4.0/.

